\title{
PROSTATE-SPECIFIC ANTIGEN DYNAMICS IN DIAGNOSIS OF PROSTATE CANCER
}

\author{
Aleksandar Skakić1,2, Ivan Ignjatović1,2, Dragoslav Bašić1,2, Andrej Veljković1, \\ Gordana Kocić ${ }^{1}$
}

\begin{abstract}
Prostate-specific antigen (PSA) is now globally applied as the best serum marker for diagnosis and monitoring of prostate cancer (CaP), but with certain limitations in terms of specificity and sensitivity. The upper limit for a normal PSA level of $4 \mathrm{ng} / \mathrm{ml}$ was suggested in 1986. In the PCPT study, PSA sensitivity (for a $4 \mathrm{ng} / \mathrm{ml}$ limit) was $21 \%$ for all types of CaP, or $51 \%$ for high grade carcinoma, with only one third of patients with high PSA value having CaP. However, it has been shown that there is a continuum of risk, in which patients with higher PSA values have a higher risk for CaP. In order to increase sensitivity (increase in the number of diagnosed CaP) and specificity (reduce the number of unnecessary biopsies), there was a need for development of other parameters: PSA doubling time, PSA velocity, f/t PSA, PSA density, Prostate Health Index-PHI, 4K score test. Also, in order to optimize patients for CaPscreening, so-called nomograms and risk calculators have been created. It is still questionable whether PSA screening has an impact on patients' survival, and two of the largest, randomized, prospective studies (ERSPC and PLCO) could not resolve this question. While ERSPC showed a $27 \%$ reduction in mortality after 13 years of follow-up, PLCO study did not show the benefit of screening on tumor-specific mortality.
\end{abstract}

Acta Medica Medianae 2019;58(3):116-121.

Key words: prostate-specific antigen, prostate cancer, screening

${ }^{1}$ University of Niš, Faculty of Medicine, Niš, Serbia

${ }^{2}$ Clinic of Urology, Clinical Center Niš, Serbia

Contact: Aleksandar Skakić

Ćirila i Metodija 18/25, 18000 Niš, Serbia

E-mail: saleskaka@hotmail.com

\section{Introduction}

In order to successfully treat patients with prostate cancer, it is necessary to implement early diagnosis, adequate risk assessment and optimal treatment. In recent decades, great effort was made to find reliable and easily measurable tumor marker that could be used for early detection, staging and monitoring of the disease on a large scale. Prostatespecific antigen (PSA) is now applied globally as the best serum marker for diagnosis and monitoring of prostate cancer, but with certain limitations in terms of specificity and sensitivity (1). Elevated serum PSA, except in prostate cancer, can often be registered in benign prostatic hyperplasia and inflammatory conditions. On the other hand, significant number of 116 patients with prostate cancer may have normal PSA value (2). It is not often possible to make a difference between indolent and aggressive prostate cancers by measuring PSA level (3).

\section{History of psa}

There is a lot of controversy related to the discovery of this marker, and there is no consensus about who came to its invention first. The scientist who first conducted experiments on prostate tissue antigens was Rubin Flocks (1960.) (4). Hara et al. discovered the prostate-specific protein in the seminal fluid and named it gamma-seminoprotein (1966.) (5). However, most of the scientific community believes that the first discoverer of PSA was American scientist Richard Ablin in 1970. He isolated the antigen exclusively localized in prostatic tissue (normal, hyperplastic or malignant) which was immune and histochemical different from prostatic acid phosphatase, which was used as a diagnostic marker for prostate cancer at that time (6). The presence of PSA in serum was first registered by Papsidero et al. in 1980 , which proved that the value of PSA in serum and prostatic tissue is identical (7). Thomas Stamey and colleagues came to a revolutionary discovery in 1987, by proving that the level of serum PSA correlates with prostate cancer stage and tumor size (8). That same year, the PSA was introduced into clinical practice and approved by the FDA (Food 
and Drug Administration) as a marker for prostate cancer monitoring. PSA have been also used as a marker for prostate cancer screening since 1994. (9).

\section{Initial psa as diagnostic parameter}

Cut-off for normal PSA value with $4 \mathrm{ng} / \mathrm{ml}$ was suggested in 1986, after a study on a small group of men (472) who did not have CaP (10). Cooner et al. in a study of 1807 men over the age of 50 years, concluded that PSA $>4 \mathrm{ng} / \mathrm{ml}$ in presence of abnormal DR finding may be a predictive parameter for $\mathrm{CaP}$ (11). The same results were published in two additional studies by Catalone et al. and Brawer et al. in 1991 and 1992. This conclusion was also published in two large studies in $1992(12,13)$. PSA was approved by FDA as a screening marker for CaP after Catalone et al. suggested the cut-off value of $4 \mathrm{ng} / \mathrm{ml}$ for all age groups (14). Studies have shown that initial PSA is significant, independent, diagnostic parameter for CaP.

However, it was registered that $\mathrm{CaP}$ was not a rare case in patients with PSA $<4 \mathrm{ng} / \mathrm{ml}$. In PCPT study (Prostate Cancer Prevention Trial) 5519 men older than 55 years, which had PSA $\leq 3 \mathrm{ng} / \mathrm{ml}$ and normal DR finding, 7-year surveillance was conducted, whereby PSA value and DR examination were conducted annually. In case of abnormal DR finding and PSA $\geq 4 \mathrm{ng} / \mathrm{ml}$ prostate biopsy was conducted, while in patients in whom CaP was not diagnosed at the end of the study, biopsy was done after a 7-year surveillance period. Biopsy was positive in $15 \%$ of men who had PSA $\leq 4 \mathrm{ng} / \mathrm{ml}$, while $15 \%$ of them had high-grade cancer (Gleason score $\geq 8$ ). Sensitivity (for a cut-off value of $4 \mathrm{ng} / \mathrm{ml}$ ) was $21 \%$ for all CaP types, and $51 \%$ for high-grade CaP. Specificity was $91 \%$, and positive predictive value about $30 \%$, which means that every third male with PSA $\geq$ $4 \mathrm{ng} / \mathrm{ml}$ had CaP (15). It is evident that there is no PSA threshold below which we can be absolutely certain that the patient does not have CaP. However, it was shown that there is a risk continuum, in which patients with higher PSA levels have a higher risk for developing CaP (16) (Table 1).

\section{Increasing sensitivity and specificity of} psa

Since the initial use of PSA in the diagnosis of CaP showed some limitations, there is a need for other parameters that could possibly increase the sensitivity (increased number of diagnosed cancer) and specificity (reduce the number of unnecessary biopsies). One way to improve the specificity of PSA is setting the cut-off value in relation to age, given that the value of PSA increases with age. Therefore reference cut-off values are recommended for specific age-groups and racial affiliation (17) (Table 2).

Table 1. Continuum of risk for prostate cancer also exists at low PSA levels

\begin{tabular}{|c|c|c|c|}
\hline PSA value & $\begin{array}{l}\text { No of patients } \\
(\mathrm{N}=2950)\end{array}$ & $\begin{array}{l}\text { No of patients with CaP } \\
\qquad \begin{array}{c}(\mathrm{N}=449) \\
\text { No }(\%)\end{array}\end{array}$ & $\begin{array}{l}\text { No of patients with high grade CaP } \\
\qquad(\mathrm{N}=67) \\
\text { No of high grade CaP/No of all CaP }(\%)\end{array}$ \\
\hline$=0.5 \mathrm{ng} / \mathrm{ml}$ & 486 & $32(6.6)$ & $4 / 32(12.5)$ \\
\hline $0.6-1.0 \mathrm{ng} / \mathrm{ml}$ & 791 & $80(10.1)$ & $8 / 80(10.0)$ \\
\hline $1.1-2.0 \mathrm{ng} / \mathrm{ml}$ & 998 & $170(17.0)$ & $20 / 170(11.8)$ \\
\hline $2.1-3.0 \mathrm{ng} / \mathrm{ml}$ & 482 & 115 (23.9) & $22 / 115(19.1)$ \\
\hline $3.1-4.0 \mathrm{ng} / \mathrm{ml}$ & 193 & $52(26.9)$ & $13 / 52(25.0)$ \\
\hline
\end{tabular}

Table 2. PSA reference values by age groups and racial background

\begin{tabular}{||c||c||c||c||}
\hline $\begin{array}{c}\text { Age groups } \\
\text { (years) }\end{array}$ & $\begin{array}{c}\text { Americans of Asian origin } \\
(\mathrm{ng} / \mathrm{ml})\end{array}$ & $\begin{array}{c}\text { African Americans } \\
(\mathrm{ng} / \mathrm{ml})\end{array}$ & $\begin{array}{c}\text { Caucasian race } \\
(\mathrm{ng} / \mathrm{ml})\end{array}$ \\
\hline \hline $40-49$ & $0-2.0$ & $0-2.0$ & $0-2.5$ \\
$50-59$ & $0-3.0$ & $0-4.0$ & $0-3.5$ \\
$60-69$ & $0-4.0$ & $0-4.5$ & $0-4.5$ \\
$70-79$ & $0-5.0$ & $0-5.5$ & $0-6.5$ \\
\hline
\end{tabular}


Change of PSA value in time can serve as a diagnostic parameter. PSA Doubling Time (PSADT) is defined as the time period for which the PSA value is doubled compared to the initial value (18). It was shown that this parameter has poor diagnostic, but more significant prognostic value, particularly in patients with biochemical recurrent CaP (19). PSA velocity (PSAV) is an absolute annual increase in serum PSA expressed in $\mathrm{ng} / \mathrm{ml} /$ year. Studies have shown that an increase in PSA greater than 0.75 $\mathrm{ng} / \mathrm{ml} /$ year increases the risk of CaP in subjects whose initial PSA values were between $4-10 \mathrm{ng} / \mathrm{ml}$ (20). Some authors suggest that the cut-off value of PSAV should be complied with age. The proposed cut-off values of PSAV for the age group between $40-59$ years was $0.25 \mathrm{ng} / \mathrm{ml}, 0.5 \mathrm{ng} / \mathrm{ml}$ for the agegroup between 60-69 years, and $0.75 \mathrm{ng} / \mathrm{ml}$ for men over 70 years (21). However, unlike the initial PSA value, PSAV is not significant, independent diagnostic parameter for $\operatorname{CaP}(22,23)$.

The ratio of free and total PSA ( $f / t$ PSA) is a very important parameter in the differential diagnosis between $\mathrm{BPH}$ and $\mathrm{CaP}$, in the case where the value of PSA is in so called "gray zone" $(4-10 \mathrm{ng} / \mathrm{ml})$. CAP patients have smaller concentrations of free PSA compared to those with BPH. CaP was diagnosed in $56 \%$ of patients with $\mathrm{f} / \mathrm{t}$ PSA $<0.1$, and only in $8 \%$ of those with $f / t$ PSA $>0.25$. It is believed that the $\mathrm{f} / \mathrm{t}$ ratio has no diagnostic significance if the PSA value is $>10 \mathrm{ng} / \mathrm{ml}$ (24).

The ratio between prostate volume and PSA has a certain diagnostic value and can be calculated when the value of PSA is divided by the total prostate volume (PSA density, PSAD) or by a volume of prostate transitional zone (transitional zone PSA density, TZPSAD), measured using a transrectal ultrasound or magnetic resonance imaging. Given that increased prostate volume (benign or malignant) causes a progressive increase in PSA level, using this parameter specificity of PSA test can be increased and number of unnecessary biopsies can be reduced. It was proposed that value of PSAD $>0.15$ may be predictive for CaP (25). It is proved that PSAD has a higher diagnostic value if serum PSA is $<4$ $\mathrm{ng} / \mathrm{ml}$, while when PSA value is between $4-10 \mathrm{ng} / \mathrm{ml}$ $\mathrm{f} / \mathrm{t}$ PSA is more important diagnostic parameter (26). Chen et al. found that PSAD is superior to $f / t$ PSA, when it comes to reducing the number of unnecessary repeated biopsy in patients with PSA levels of 4-10 $\mathrm{ng} / \mathrm{ml}$ (27).

Newer studies on free PSA fraction, a marker that has significantly increased specificity of PSA test, led to the realization that he can exist in at least 3 different forms: benign PSA, intact PSA and the proPSA (28). Studies have shown that proPSA is one of the forms that could be of great importance in the diagnosis of CaP, especially its most stable serum isoform - p2PSA. This isoform is primarily present in the peripheral zone of prostate, and slightly in the transition zone of the prostate. In addition, serum p2PSA levels were significantly higher in patients with CaP than in patients without cancer (29). In order to increase the sensitivity and specificity of the test, a mathematical algorithm called Prostate Health Index (PHI) was developed, which incorporates tPSA, fPSA and P2PSA values, and is defined by the formula: $\mathrm{PHI}=($ p2PSA / fPSA) $\times($ tPSA) $1 / 2$ (30). Compared to standard markers for the detection of CaP which showed a lot of uncertainty, p2PSA and $\mathrm{PHI}$ were imposed as a potentially better and more specific for the detection of CaP, particularly in PSA levels of $2-10 \mathrm{ng} / \mathrm{ml}$ (31).

$4 \mathrm{~K}$ test score is one of the newest diagnostic tests, in which by using four individual kallikreins (total, free, intact PSA and kallikrein-related peptidase 2 ) the risk of aggressive CaP is determined. This test combines test results with data such as age, DR finding and previous prostate biopsy finding. Large prospective studies showed significant predictive value of this test for poorly differentiated CaP (Gleason score $\geq 7$ ) (32).

\section{Advantages and disadvantages of global application of psa screening CaP}

Screening for prostate cancer has an opportunistic character, which means non-systematic testing in men who themselves appear to urological examination. There is no doubt that the PSA era has led to increased detection of CaP, especially in the earlier stages, as well as a significant reduction in metastatic disease (33). When it comes to the impact on survival, two largest, randomized, prospective studies could not answer the question if massive use of PSA is justified or not: ERSPC (European Randomized Study for Prostate Cancer) and PLCO (Prostate, Lung, Colorectal and Ovary trial).

While ERSPC after 13 years of follow-up showed a reduction in mortality of $27 \%$, the PLCO study showed no benefit of screening in terms of tumor-specific mortality. However, there are certain differences in methodological approach between these two studies that should be noted.

PLCO study involved 76,693 respondents aged between 55-74 years, which had PSA test and DR examination carried out once a year. ERSPC study, in which the results of several small studies were summarized, included 162, 243 respondents aged between 55-69 years, while the measurement of PSA was done mainly on a 4 year-interval. Almost half of the men before pulling into the PLCO study underwent PSA testing, unlike ERSPC study, where subjects were not previously screened. The PLCO study also recorded slightly lower compliance of patients in the screening group, in terms of responding to urological examination and prostate biopsy, and also a higher percentage of respondent contamination in the control group (52\%). However, the major methodological diversity between two studies was PSA threshold taken as a trigger for prostate biopsy. PSA > $4 \mathrm{ng} / \mathrm{ml}$ or abnormal DR finding were an indication for biopsy in the PLCO study, while in ERSPC study, PSA value of $3 \mathrm{ng} / \mathrm{ml}$ was used in most cases as a threshold. Regardless of this fact, two studies demonstrated an increased incidence of CaP in a screening group compared to the control group. The largest percentage of these cancers was localized, well-differentiated cancers $(34,35)$. The fact that a large number of these indolent cancers were subjected to some form of active treatment is indicative of so-called overdiagnosis and overtreatment problem. In other words, due to discovery of a 
large number of clinically insignificant CaP (overdiagnose), a significant number of these patients are subjected to treatment that does not cause prognostic benefit and post-treatment complications can often reduce the quality of life of patients (overtreatment) (36). It is estimated that it is necessary to implement screening of 781 men, and actively treat 27 men diagnosed with $\mathrm{CaP}$, in order to directly prevent one death from CaP (34).

In order to optimize patients for CaP screening, there was a need for the creation of so-called risk calculators and nomograms. They represent a special scheme which contains parameters such as: age, DR finding, race, family history, previous prostate biopsies, tPSA and FPSA, and based on these data, calculate the risk for CaP and its aggressive form. In accordance with these findings, recommendations are given for further follow-up, or if there is an indication, prostate biopsy is considered. The ultimate goal is to reduce the overdiagnosis problem, but simultaneously to reduce the tumor-specific mortality by aggressive and poorly-differentiated tumors being diagnosed at an early stage (37). Several nomograms have been presented in current practice but none of them shown superiority in comparison to others (38). Memorial Sloan Kettering Cancer Center has recently outlined the scheme for CaP screening: begin screening at age 45 ; if PSA is $<1 \mathrm{ng} / \mathrm{ml}$ repeat testing in 6-10 years; if PSA is $\geq 1$ and $<3 \mathrm{ng} / \mathrm{mL}$ repeat testing in $2-4$ years; if the PSA $\geq 3 \mathrm{ng} / \mathrm{ml}$ prostate biopsy is considered. In making decisions for prostate biopsy, we should consider: risk factors (family history, racial origin), previous prostate biopsies, PSA dynamics and whether there is an inflammatory component as the cause of PSA elevation (antibiotic prophylaxis). Screening should be discontinued at age 60 if PSA value is $\leq 1 \mathrm{ng} / \mathrm{ml}$, or at age 75 if the PSA level in the normal range (39).

\section{Conclusion}

The widespread use of PSA has led to the discovery of a large number of indolent cancers, which led to the problem of overdiagnosis and overtreatment. On the other hand, CaP in its aggressive form continues to cause significant morbidity and mortality in the male population. In the absence of hard evidence about the benefits of global screening, but with due caution when taking into account the positive effects of PSA testing, opportunistic screening should be conducted. Therefore, it is necessary to stratify patients in groups on the basis of initial PSA and other parameters, and based on that, to propose a scheme for determining PSA individually.

\section{Acknowledgements}

This study was supported by the Faculty of Medicine, University in Niš, Internal scientific project number 31 .
1. Hadži-Đokić J. [Prostate Cancer]. In: Pejčić T, HadžiĐokić J, Bašić D. [Prostate]. $1^{\text {st }}$ ed. Belgrade: Elit Medica; 2014.p.144. Serbian.

2. Tchetgen MB, Oesterling JE. The role of prostate-specific antigen in the evaluation of benign prostatic hyperplasia. Urol Clin North Am 1995; 22(2):333-44. [PubMed]

3. Thompson IM, Ankerst DP, Chi C, Lucia MS, Goodman $\mathrm{PJ}$, Crowley JJ, et al. Operating characteristics of prostate-specific antigen in men with an initial PSA level of $3.0 \mathrm{ng} / \mathrm{ml}$ or lower. JAMA 2005;294(1):66-70. [PubMed] [CrossRef]

4. Flocks $R H$, Urich VC, Patel CA, Opitz JM. Studies on the antigenic properties of prostatic tissue. I Jurol 1960;84:134-43. [CrossRef]

5. Hara M, Inoue T, Koyanagi Y. Preparation and immunoelectrophoretic assessment of antisera to human seminal plasma. Nippon Hoigaku Zasshi 1966;20:356.
6. Ablin RJ, Soanes WA, Bronson P, Witebsky E. Precipitating antigens of the normal human prostate. J Reprod Fertil 1970; 22(3):573-4. [PubMed] [CrossRef]

7. Papsidero LD, Wang MC, Valenzuela LA, Murphy GP, Chu TM. A prostate antigen in sera of prostatic cancer patients. Cancer Res 1980;40(7):2428-32. [PubMed]

8. Stamey TA, Yang N, Hay AR, McNeal JE, Freiha FS, Redwine E. Prostate-specific antigen as a serum marker for adenocarcinoma of the prostate. N Engl J Med 1987;317(15):909-16. [PubMed] [CrossRef]

9. De Angelis G, Rittenhouse HG, Mikolajczyk SD, Blair Shamel L, Semjonow A. Twenty Years of PSA: From Prostate Antigen to Tumor Marker. Rev Urol 2007; 9(3):113-23. [PubMed]

10. Myrtle JF, Klimley PG, Ivor IP, Bruni JF. Clinical utility of prostate specific antigen (PSA) in the management of prostate cancer. In: Scaten R, editor. Advances in cancer diagnosis. San Diego: Hybritec Inc;1986.p.1-4. 
11. Cooner WH, Mosley BR, Rutherford CL Jr, Beard JH, Pond HS, Terry WJ, et al. Prostate cancer detection in a clinical urological practice by ultrasonography, digital rectal examination and prostate specific antigen. J Urol 1990;143(6):1146-52. [PubMed] [CrossRef]

12. Catalona WJ, Smith DS, Ratliff TL, Dodds KM, Coplen $D E$, Yuan JJ, et al. Measurement of prostate-specific antigen in serum as a screening test for prostate cancer. N Engl J Med 1991;324(17):1156-61.

\section{[PubMed] [CrossRef]}

13. Brawer MK, Chetner MP, Beatie J, Buchner DM, Vessella $\mathrm{RL}$, Lange $\mathrm{PH}$. Screening for prostatic carcinoma with prostate specific antigen. J Urol 1992;147(3): 841-5. [CrossRef]

14. Catalona WJ, Hudson MA, Scardino PT, Richie JP, Ahmann FR, Flanigan RC. Selection of optimal prostate specific antigen cutoffs for early detection of prostate cancer: receiver operating characteristic curves. J Urol 1994;152(1):2037-42. [PubMed] [CrossRef]

15. Thompson IM, Ankerst DP, Chi C, Goodman PJ, Tangen CM, Lucia MS. Assessing prostate cancer risk: results from the Prostate Cancer Prevention Trial. ] Natl Cancer Inst 2006;98(8):529-34. [PubMed] [CrossRef]

16. Greene KL, Albertsen PC, Babaian RJ, Carter HB, Gann $\mathrm{PH}$, Han M. Prostate specific antigen best practice statement: 2009 update. J Urol 2009;182(5):2232-41. [PubMed] [CrossRef]

17. Reed A, Ankerst DP, Pollock BH, Thompson IM, Parekh DJ. Current age and race adjusted prostate specific antigen threshold values delay diagnosis of high grade prostate cancer. J Urol 2007;178(5):1929-32. [PubMed] [CrossRef]

18. Vickers AJ, Brewster SF. PSA Velocity and Doubling Time in Diagnosis and Prognosis of Prostate Cancer. $\mathrm{Br}$ J Med Surg Urol 2012;5(4):162-8. [PubMed] [CrossRef]

19. Roberts SG, Blute ML, Bergstralh EJ, Slezak JM, Zincke $H$. PSA doubling time as a predictor of clinical progression after biochemical failure following radical prostatectomy for prostate cancer. Mayo Clin Proc 2001; 76(6):576-81. [PubMed] [CrossRef]

20. Carter HB, Pearson JD, Metter EJ, Brant L, Chan DW, Andres R. Longitudinal evaluation of prostate-specific antigen levels in men with and without prostate disease. JAMA 1992;267(16):2215-20. [PubMed] [CrossRef]

21. Moul JW, Sun L, Hotaling JM Fitzsimons NJ, Polascik TJ, Robertson CN, et al. Age adjusted prostate specific antigen and prostate specific antigen velocity cut points in prostate cancer screening. J Urol 2007;177 (2):499-503. [PubMed] [CrossRef]

22. Etzioni RD, Ankerst DP, Weiss NS, Inoue LY, Thompson IM. Is prostate-specific antigen velocity useful in early detection of prostate cancer? A critical appraisal of the evidence. J Natl Cancer Inst 2007; 99(20):1510-5. [PubMed] [CrossRef]

23. Raaijmakers $R$, Wildhagen $M F$, Ito $K$, Pàez $A$, de Vries $\mathrm{SH}$, Roobol MJ, et al. Prostate-specific antigen change in the European Randomized Study of Screening for Prostate Cancer, section Rotterdam. Urology 2004;63 (2):316-20. [PubMed] [CrossRef]

24. Catalona WJ, Partin AW, Slawin KM, Brawer MK, Flanigan RC, Patel $A$, et al. Use of the percentage of free prostate-specific antigen to enhance differentiation of prostate cancer from benign prostatic disease: a prospective multicenter clinical trial. JAMA 1998; 279(19):1542-7. [PubMed] [CrossRef]

25. Benson MC, Whang IS, Pantuck A, Ring K, Kaplan SA, Olsson CA, et al. Prostate specific antigen density: a means of distinguishing benign prostatic hypertrophy and prostate cancer. J Urol 1992;147(3):815-6.

[PubMed] [CrossRef]

26. Stephan C, Stroebel G, Heinau M, Lenz A, Roemer A, Lein $M$, et al. The ratio of prostate-specific antigen (PSA) to prostate volume (PSA density) as a parameter to improve the detection of prostate carcinoma in PSA values in the range of $<4 \mathrm{ng} / \mathrm{mL}$. Cancer 2005; 104(5):993-1003. [PubMed] [CrossRef]

27. Chen CS, Wang SS, Li JR, Cheng $C L$, Yang CR, Chen WM, et al. PSA density as a better predictor of prostate cancer than percent-free PSA in a repeat biopsy. J Chin Med Assoc 2011;74(12):552-5. [PubMed] [CrossRef]

28. Mikolajczyk SD, Marks LS, Partin AW, Rittenhouse HG. Free prostate-specific antigen in serum is becoming more complex. Urology 2002;59:797-802. [PubMed] [CrossRef]

29. Mikolajczyk SD, Millar LS, Wang TJ, Rittenhouse HG, Marks LS, Song W, et al. A precursor form of prostatespecific antigen is more highly elevated in prostate cancer compared with benign transition zone prostate tissue. Cancer Res 2000;60(3):756-9. [PubMed]

30. Loeb S, Catalona WJ. The Prostate Health Index: a new test for the detection of prostate cancer. Ther Adv Urol 2014; (2):74-7. [PubMed] [CrossRef]

31. Jansen FH, van Schaik RHN, Kurstjens J, Horninger W, Klocker $\mathrm{H}$, Bektic $\mathrm{J}$, et al. Prostate-specific antigen (PSA) isoform p2PSA in combination with total PSA and free PSA improves diagnostic accuracy in prostate cancer detection. Eur Urol 2010;57(6):921-7. [PubMed] [CrossRef]

32. Parekh DJ, Punnen S, Sjoberg DD, Asroff SW, Bailen JL, Cochran JS, et al. A multi-institutional prospective trial in the USA confirms that the $4 \mathrm{~K}$ score accurately identifies men with high-grade prostate cancer. Eur Urol 2015;68:464. [PubMed] [CrossRef]

33. Schröder FH, Hugosson J, Carlsson $S$, Tammela $T$, Määttänen $L$, Auvinen $A$, et al. Screening for prostate cancer decreases the risk of developing metastatic disease: findings from the European Randomized Study of Screening for Prostate Cancer (ERSPC). Eur Urol 2012;62(5):745-52. [PubMed] [CrossRef]

34. Schröder FH, Hugosson J, Roobol MJ, Tammela TL, Zappa M, Nelen V. Screening and prostate cancer mortality: results of the European Randomised Study of Screening for Prostate Cancer (ERSPC) at 13 years of follow-up. Lancet 2014 6;384(9959):2027-35. [PubMed]

35. Andriole GL, Crawford ED, Grubb RL, Buys SS, Chia D, Church Tr, et al. Prostate Cancer Screening in the Randomized Prostate, Lung, Colorectal, and Ovarian Cancer Screening Trial: Mortality Results after 13 Years of Follow-up. J Natl Cancer Inst 2012;104(2): 125-32. [PubMed] [CrossRef]

36. Loeb $S$, Bjurlin $M$, Nicholson J, Tammela TL, Penson DF, Carter HB, et al. Overdiagnosis and Overtreatment of Prostate Cancer. Eur Urol 2014;65(6):104655. [PubMed] [CrossRef]

37. Lowrance WT, Scardino PT. Predictive Models for Newly Diagnosed Prostate Cancer Patients. Rev Urol 2009; 11(3):117-26. [PubMed]

38. Louie KS, Seigneurin A, Cathcart P, Sasieni P. Do prostate cancer risk models improve the predictive accuracy of PSA screening? A meta-analysis. Ann Oncol 2015;26(5):848-64. [PubMed] [CrossRef]

39. Vickers AJ, Eastham JA, Scardino PT, Lilja H. The Memorial Sloan Kettering Cancer Center Recommendations for Prostate Cancer Screening. Urology 2016; 91:12-8. [PubMed] [CrossRef] 


\title{
DINAMIKA SPECIFIČNOG ANTIGENA PROSTATE U DIJAGNOSTICI KARCINOMA PROSTATE
}

\author{
Aleksandar Skakić1,2, Ivan Ignjatović1,2, Dragoslav Bašić1,2, Andrej Veljković1, \\ Gordana Kocić ${ }^{1}$
}

${ }^{1}$ Univerzitet u Nišu, Medicinski fakultet, Niš, Srbija

Kontakt: Aleksandar Skakić

Ćirila i Metodija 18/25, 18000 Niš, Srbija

E-mail: saleskaka@hotmail.com

Prostata specifični antigen (PSA) danas se globalno primenjuje kao najbolji serumski marker za dijagnostiku i praćenje karcinoma prostate (CaP), ali sa određenim ograničenjima, u smislu specifičnosti i senzitivnosti. Gornja granica za normalne vrednosti PSA od $4 \mathrm{ng} / \mathrm{ml}$ predložena je 1986. godine. U PCPT studiji senzitivnost PSA (za graničnu vrednost od $4 \mathrm{ng} /$ $\mathrm{ml}$ ) bila je $21 \%$ za sve tipove CaP, odnosno $51 \%$ za karcinome visokog gradusa, pri čemu je tek svaki treći muškarac sa visokim vrednostima PSA imao CaP. Ipak, pokazano je da postoji kontinuum rizika po kojem bolesnici sa većim vrednostima PSA imaju veći rizik od oboljevanje od CaP. U cilju povećanja senzitivnosti (povećanja broja dijagnostikovanih karcinoma) i specifičnosti (smanjenja broja nepotrebnih biopsija) javila se potreba i za drugim parametrima: PSA doubling time, PSA velocity, f/t PSA, PSA density, Prostate Health Index - PHI, 4K score test. Takođe se, u cilju optimizacije bolesnika za skrining CaP izrađuju i tzv. nomogrami i kalkulatori rizika. Kada je reč o uticaju skrininga PSA na preživljavanje, pitanje opravdanosti masovne upotrebe PSA nisu uspele da razreše ni dve najveće, randomizovane, prospektivne studije: ERSPC studija i PLCO studija. Dok je ERSPC nakon 13 godina praćenja pokazala redukciju mortaliteta za $27 \%$, studija PLCO nije pokazala korist skrininga u pogledu tumor specifičnog mortaliteta.

Acta Medica Medianae 2019;58(3):116-121.

KIjučne reči: specifični antigen prostate, karcinom prostate, skrining 